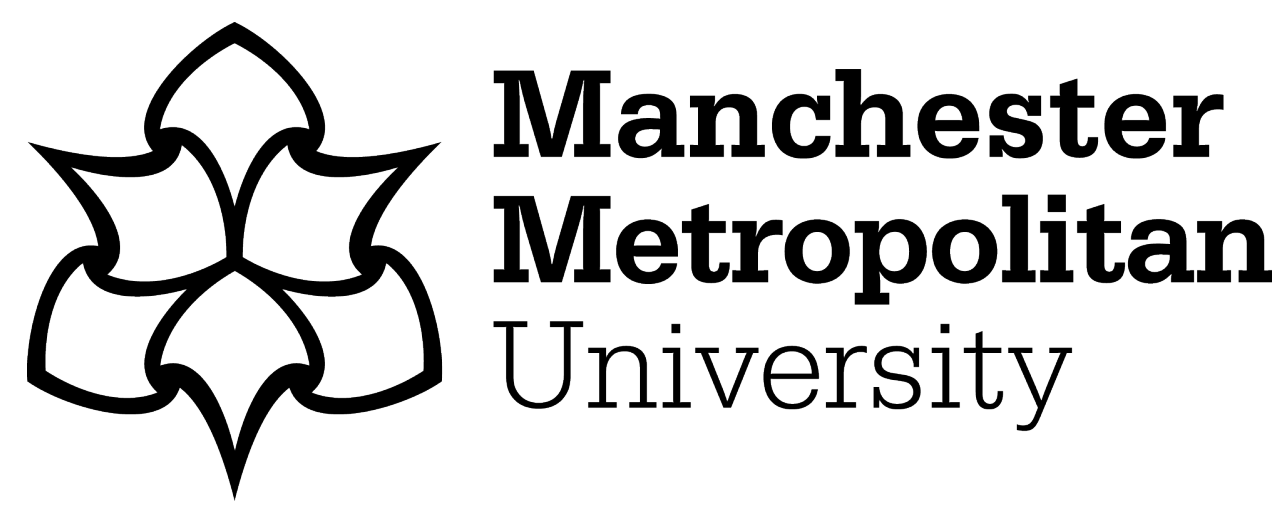

Mekasuwandumrong, O, Jantarasorn, N, Panpranot, J, Ratova, M, Kelly, P ORCID logoORCID: https://orcid.org/0000-0003-1008-4941 and Praserthdam, P (2019) Synthesis of $\mathrm{Cu} / \mathrm{TiO} 2$ catalysts by reactive magnetron sputtering deposition and its application for photocatalytic reduction of $\mathrm{CO} 2$ and $\mathrm{H} 2 \mathrm{O}$ to $\mathrm{CH} 4$. Ceramics International, 45 (17B). ISSN 0272-8842

Downloaded from: https://e-space.mmu.ac.uk/624116/

Version: Accepted Version

Publisher: Elsevier

DOI: https://doi.org/10.1016/j.ceramint.2019.07.340

Please cite the published version 


\section{Synthesis of $\mathrm{Cu} / \mathrm{TiO}_{2}$ catalysts by reactive magnetron sputtering deposition and its}

\section{application for photocatalytic reduction of $\mathrm{CO}_{2}$ and $\mathrm{H}_{2} \mathrm{O}$ to $\mathrm{CH}_{4}$}

Okorn Mekasuwandumrong ${ }^{1}$, Nantiya Jantarasorn ${ }^{2}$, Joongjai Panpranot ${ }^{2}$, Marina Ratova ${ }^{3}$, Peter Kelly ${ }^{3}$ and

$$
\text { Piyasan Praserthdam², }
$$

${ }^{I}$ Department of Chemical Engineering, Faculty of Engineering and Industrial Technology, Silpakorn University,

$$
\text { Nakorn Pathom 73000, Thailand }
$$

${ }^{2}$ Center of Excellence on Catalysis and Catalytic Reaction, Department of Chemical Engineering, Faculty of Engineering, Chulalongkorn University, Bangkok, 10330, Thailand

${ }^{3}$ Surface Engineering Group, Faculty of Science and Engineering, Manchester Metropolitan University, Manchester, M1 5GD, United Kingdom 


\section{$\underline{\text { Abstract }}$}

In the present work, a series of $\mathrm{Cu} / \mathrm{TiO}_{2}$ catalysts were successfully synthesized by using pulsed direct current $(\mathrm{DC})$ reactive magnetron sputtering of $\mathrm{Cu}$ targets under Ar atmosphere onto various $\mathrm{TiO}_{2}$ supports. The physiochemical properties of the catalysts were characterized by using inductive coupled plasma spectroscopy (ICP), X-ray diffraction (XRD), UV-Vis spectroscopy, $\mathrm{N}_{2}$ physisorption, transmission electron microscopy (TEM), PL spectroscopy, and X-ray photoelectron spectroscopy (XPS). The photocatalytic activities of all the catalysts were studied via the photocatalytic reduction of $\mathrm{CO}_{2}$ and $\mathrm{H}_{2} \mathrm{O}$ to $\mathrm{CH}_{4}$ under $\mathrm{UV}$ light irradiation. The $\mathrm{Cu} / \mathrm{TiO}_{2}$ catalysts exhibited higher photocatalytic activity than the uncoated $\mathrm{TiO}_{2}$ supports and the ones made using an impregnation technique. The electron trapping of copper species, which prolonged the electron-hole recombination process, promoted photocatalytic activity of the $\mathrm{Cu}$ doped catalysts. Moreover, the specific morphologies of the $\mathrm{Cu}$ species deposited on $\mathrm{TiO}_{2}$ supports and the smaller change of bandgap energy of the sputter coated catalysts also resulted in an improvement of photocatalytic activity under UV light irradiation.

Keywords: photocatalytic; $\mathrm{CO}_{2}$ reduction; $\mathrm{Cu} / \mathrm{TiO}_{2}$; methane; magnetron sputtering 


\section{Introduction}

Presently, climate change and global warming are among the most serious environmental issues. The increase of atmospheric greenhouse gas concentration is widely considered as the main driving factor. Emission of $\mathrm{CO}_{2}$ has the greatest impact on global warming, due to its relatively high emission to the atmosphere compared to other greenhouse gases $[1,2]$. The main contributors of $\mathrm{CO}_{2}$ emission are from power production, combustion of industrial fuels, construction, agriculture, and transportation. The solution to the problems is to reduce the release of $\mathrm{CO}_{2}$ gas into the atmosphere or to convert it into other usable products. $\mathrm{CO}_{2}$ can be used to generate valuable products, including methane, polycarbonate, methanol, acetic acid, formaldehyde, etc. [3-5] .

Photocatalytic reduction of $\mathrm{CO}_{2}$ is an interesting process to convert $\mathrm{CO}_{2}$ to various products such as carbon monoxide $(\mathrm{CO})$ [6], methane $\left(\mathrm{CH}_{4}\right)$ [7], methanol $\left(\mathrm{CH}_{3} \mathrm{OH}\right)$ [8], formic acid $(\mathrm{HCOOH})$ [9], and formaldehyde $(\mathrm{HCHO})$ [10]. With this technology, $\mathrm{CO}_{2}$ is reduced with water as a reducing agent with UV light irradiation at room temperature and atmospheric pressure [11]. This process is relatively low cost, environmental friendly, and does not require thermal energy. Many photocatalysts have been attentively studied in this reaction [12]. Among those, $\mathrm{TiO}_{2}$ is used most extensively due to its high stability, high photosensitivity, non-toxic nature, wide availability, and low cost [13]. However, $\mathrm{TiO}_{2}$ has a high electron-hole pair recombination rates and weak $\mathrm{CO}_{2}$ adsorption, which leads to low photocatalytic activity[14].

In order to improve the efficiency of $\mathrm{TiO}_{2}$ in photocatalytic $\mathrm{CO}_{2}$ reduction, it is necessary to increase the lifetime of the photogenerated electrons and holes via effective charge carrier separation and retardation of electron-hole recombination rate [15]. To accomplish this goal, 
many methods have been proposed. It is well known that the structure and morphology of photocatalysts materials are critical to their photocatalytic performances [16-19]. Therefore, the effect of morphologies on the photocatalysts materials has been extensively studied. Doping $\mathrm{TiO}_{2}$ with many kinds of metal/non-metal such as $\mathrm{Cu}[20]$, $\mathrm{Pt}[21], \mathrm{Au}[22], \mathrm{Ag}[23]$, and $\mathrm{B}[24]$ can also improve the photocatalytic efficiency of $\mathrm{TiO}_{2}$. In a number of previous studies, deposition of $\mathrm{Cu}$ nanoparticles onto $\mathrm{TiO}_{2}$ surface has been found to improve the photocatalytic efficiency of $\mathrm{TiO}_{2}$ by altering the bandgap and preventing the recombination of photogenerated electron-hole pairs, which showed effectiveness in $\mathrm{CO}_{2}$ photoreduction [25]. Besides, $\mathrm{Cu}$ nanoparticles were selected due to their high yield of methane formation [7, 26].

In general, the preparation of metal doped $\mathrm{TiO}_{2}$ catalysts is mostly done by conventional impregnation method, which usually requires a metal precursor solution and heat treatment, which generates waste. Reactive magnetron sputtering is a commercial process to prepare a thin film product for various applications ranging from solar glazing products to micro-electronic coatings, from tool protecting layers to packaging coatings [27]. Applying this method to prepare powder products can offer a new direct metal deposition method on a powder support, which can be carried out in a one-step process without generation of waste [28].

In this work, we present the results of the deposition of $\mathrm{Cu}$ clusters on various $\mathrm{TiO}_{2}$ supports by using the pulsed magnetron sputtering technique and compare these samples with the ones prepared by a conventional impregnation method. The physiochemical properties of the obtained-catalysts were characterized and their photocatalytic properties were tested in the photocatalytic reduction of $\mathrm{CO}_{2}$ and $\mathrm{H}_{2} \mathrm{O}$ to $\mathrm{CH}_{4}$.

\section{Experimental}




\subsection{Catalytic preparation}

The $\mathrm{Cu} / \mathrm{TiO}_{2}$ catalysts were prepared by using the pulsed magnetron sputtering method to deposit $\mathrm{Cu}$ on various $\mathrm{TiO}_{2}$ supports. Three types of $\mathrm{TiO}_{2}$ including $\mathrm{P} 25$, pure anatase $\mathrm{TiO}_{2}$ and pure rutile $\mathrm{TiO}_{2}$ were used as the catalyst supports. $2 \mathrm{~g}$ of each $\mathrm{TiO}_{2}$ support was loaded in the sputtering chamber. The $\mathrm{TiO}_{2}$ powder was placed in an oscillating bowl positioned directly underneath the $75 \mathrm{~mm}$ diameter $\mathrm{Cu}$ sputtering target. The oscillator caused the powder particles to move around the bowl during the deposition process and, therefore, resulted in a uniform coating on the substrate. The synthesis conditions including power; $200 \mathrm{~W}$ and pulse frequency (F); $200 \mathrm{kHz}$ were used. The pulsed magnetron sputtering of the $\mathrm{Cu}$ target was done in an argon atmosphere at $2 \mathrm{~Pa}$. The sputtering time was varied at 2.5, 5, and $7.5 \mathrm{~min}$.

For comparison purposes, $\mathrm{Cu} / \mathrm{TiO}_{2}$ catalysts were also prepared by the conventional incipient wetness impregnation method. Approximately $2 \mathrm{~g}$ of $\mathrm{TiO}_{2}$ was doped with an aqueous solution of copper (II) nitrate trihydrate $\left(\mathrm{Cu}\left(\mathrm{NO}_{3}\right)_{2} \cdot 3 \mathrm{H}_{2} \mathrm{O}\right)$. The metal precursor solution was slowly dropped onto the $\mathrm{TiO}_{2}$ supports to obtain the desired content. The obtained sample was dried in an oven at $110^{\circ} \mathrm{C}$ overnight and then calcined in a box furnace at $400^{\circ} \mathrm{C}$ under an air flow with a heating rate $10^{\circ} \mathrm{C} / \mathrm{min}$ and held at that temperature for $2 \mathrm{~h}$.

\subsection{Catalyst characterization}

The crystal structures of catalyst particles were examined by powder X-ray diffraction (XRD) using a SIEMENS XRD D5000 X-ray diffractometer with $\mathrm{CuK}_{\alpha}$ radiation. The scans 
were recorded over a range of $2 \theta$ angles from $10^{\circ}$ to $80^{\circ}$. The average crystallite size of the catalysts was calculated from line broadening according to Scherrer's equation. The amount of $\mathrm{Cu}$ loading in catalysts were measured by Inductively Coupled Plasma- Optical Emission Spectroscopy (ICP-OES) using Perkin Elmer Optima 7000DV. The BET surface area was obtained from the nitrogen adsorption isotherm at $77 \mathrm{~K}$ using a BEL-SORP automated system. The band gap energy of catalysts was determined by UV-Vis spectrometer using LAMDA 650 $\mathrm{UV} / \mathrm{Vis}$ spectrophotometer to study in electronic properties. The morphologies of the $\mathrm{Cu} / \mathrm{TiO}_{2}$ catalysts were determined by transmission electron microscope (TEM) using a JEOL- JEM 2010 transmission electron microscope using energy-dispersive $\mathrm{X}$-ray detector operated at $200 \mathrm{kV}$. The surface properties was determined by using X-ray photoelectron spectroscopy (XPS) using ANICUS photoelectron spectrometer equipped with a $\mathrm{Mg} \mathrm{K} \alpha$ that $\mathrm{X}$-ray as a primary excitation and a KRATOS VISION 2 software. The photoluminescence spectroscopy (PL) was examined using Fluromax ${ }^{\circledR}$ by Horiba and using Xenon lamp source excitation at $320 \mathrm{~nm}$. The thermogravimetric analysis was examined with air by using SDT Q600 V8.3 Build 101.

\subsection{Photocatalytic reaction}

The photocatalytic reductions of $\mathrm{CO}_{2}$ with water were carried out in a photoreactor system. Six UV-light bulbs were installed around a cylindrical quartz reactor. $0.5 \mathrm{~g}$ of catalyst was dispersed into a stirred slurry reactor (SSR), which contained $150 \mathrm{~mL}$ of deionized water. Prior to the reaction test, compressed $\mathrm{CO}_{2}(>99.99 \%)$ was flowed into the system from an inlet 
tube in the cylindrical quartz reactor with a flow rate of $100 \mathrm{ml} / \mathrm{min}$ using a mass flow controller for $30 \mathrm{~min}$. to eliminate other gases and saturate the solution. During the reaction, the reactor is closed and a magnetic stirrer agitated the catalyst-suspended solution throughout the experiment. The photocatalytic reaction was started by turned on the UV light, and irradiation was continued for $6 \mathrm{~h}$. The resultant gas samples were analyzed using a two GC14B (Shimadzu) gas chromatographs equipped with a flame ionization detector (FID) and thermal conductivity detector for hydrocarbon and other gases analysis. The photocatalytic reaction was performed for $2 \mathrm{~h}$ and the methane production yield can be calculated according to the following equation:

$$
\mathrm{CH}_{4} \text { production yield }=\frac{\text { Total amount of } \mathrm{CH}_{4} \text { evolved per g of catalyst }\left(\mu \mathrm{mol} \text {. gcat }{ }^{-1}\right)}{\text { Reaction time }(\mathrm{h})}
$$

The quantum efficiencies of the photocatalysts were measured under the same photocatalytic reaction conditions. The light intensity was estimated using a research radiometer (MODE IL-1700). The QE for $\mathrm{CO}_{2}$ reduction to $\mathrm{CH}_{4}$ was calculated using the following equation:

$$
\begin{gathered}
\text { QE }(\%)=\frac{\text { number of reacted electrons }}{\text { number of incident photons }} \times 100 \\
\text { QE }(\%)=\frac{8 \times \text { number of evolved } \mathrm{CH}_{4} \text { molecules }}{\text { number of incident photons }} \times 100
\end{gathered}
$$




\section{Results and discussion}

\subsection{Characterization of the sputtered $\mathrm{Cu} / \mathrm{TiO}_{2}$ catalysts}

The XRD patterns of all the sputtered- and the impregnation-made catalysts are shown in Figure 1. Both sputtered- and impregnation-made $\mathrm{Cu}$ deposited on $\mathrm{P} 25$ and anatase $\mathrm{TiO}_{2}$ catalysts exhibited the main characteristic peaks of the anatase phase located at $2 \theta=25.3$ (101), 37.8 (004), 48.0 (200), 54.5, (105 and 211), and 62.8 (213). The additional peaks of the rutile phase were only observed for $\mathrm{Cu}$ supported on P25 catalysts at $2 \theta$ degrees $=27.5(110)$. In the case of $\mathrm{Cu}$ deposited on rutile $\mathrm{TiO}_{2}$, only the characteristic peaks of the rutile phase were observed. There were no additional peaks corresponding to $\mathrm{Cu} / \mathrm{CuO}$ phases in all the sputterred- and impregnation- made catalysts. This is probably due to the low amount of $\mathrm{Cu}$ loading and/or high dispersion of $\mathrm{Cu} / \mathrm{CuO}$ on the $\mathrm{TiO}_{2}$ supports. The physical properties such as crystallite size, BET surface area and band gap energy of all the catalysts are summarized in Table 1. It can be seen that deposition of $\mathrm{Cu}$ by both methods did not affect the crystal structure, crystallite size, and $\mathrm{BET}$ surface area of the $\mathrm{Cu} / \mathrm{TiO}_{2}$ catalyst even after prolonging the sputtering time or increasing of $\mathrm{Cu}$ loading content.

The actual amount of $\mathrm{Cu}$ loading of all the sputtered-catalysts were measured by using ICP technique. A Plot showing the relationship between \% $\mathrm{Cu}$ loading content and sputtering time is shown in Figure 2. The Cu contents increased linearly with sputtering time, due to the constant flux of $\mathrm{Cu}$ atoms deposited on the supports. The amount of $\mathrm{Cu}$ increased in the order of $\mathrm{P} 25>$ rutile $>$ anatase. The differences in $\mathrm{Cu}$ loadings could be attributed to the different powder distribution patterns in the oscillating bowl. In order to compare the $\mathrm{Cu} / \mathrm{TiO}_{2}$ catalysts 
prepared by different methods, the catalysts with similar \% $\mathrm{Cu}$ loading content were also prepared by impregnation and the ICP results are summarized in Table 1.

The UV-Vis absorption spectra of the sputtered catalysts are shown in Figure 3. Typical absorption spectra of $\mathrm{Cu}$ modified $\mathrm{TiO}_{2}$ materials consisted of three main characteristic bands, including the sharp absorption band at wavelengths less than $400 \mathrm{~nm}$, which were attributed to the band structure of the original $\mathrm{TiO}_{2}$, the absorption band at wavelengths of $700-800 \mathrm{~nm}$, due to the $\mathrm{Cu} d-\mathrm{d}$ transition, and an absorption tail in the $400-500 \mathrm{~nm}$ region, which was attributed to the interfacial charge transfer (IFCT) phenomenon between $\mathrm{TiO}_{2}$ valence band electrons and $\mathrm{Cu}(\mathrm{II})$ species. The impregnation-made catalysts exhibited all three adsorption bands and the peak intensity increased with increasing of $\mathrm{Cu}$ loading content, indicating the formation of $\mathrm{Cu}$ nanoparticles and the interaction between $\mathrm{Cu}$ (II) species and the $\mathrm{TiO}_{2}$ support. On the other hand, the sputtered catalysts exhibited typical adsorption bands of the $\mathrm{TiO}_{2}$ and $\mathrm{Cu}$ nanoparticles but the absorption tail between 400 and $500 \mathrm{~nm}$ related to IFCT was absent or much less apparent.

The band gap energy of all the $\mathrm{Cu} / \mathrm{TiO}_{2}$ samples were determined from the extrapolation of Tauc plots of $(\mathrm{hv} \alpha)^{1 / 2}$ as a function of photon energy (hv) and the obtained results are shown in Table 1. For the impregnation-made catalysts, the band gap of the $\mathrm{TiO}_{2}$ supports shifted towards longer wavelengths after doping with $\mathrm{Cu}$. However, in the case of the sputtered catalysts, only a small shift was observed. This indicates that there was less interaction between the $\mathrm{Cu}$ and the $\mathrm{TiO}_{2}$ supports when prepared by the sputtering method. The differences in the interaction between the sputtered coating and the support could be attributed to the different temperatures used in the deposition process. In the impregnation process, the 
catalysts were subjected to heat treatment at $400^{\circ} \mathrm{C}$ in order to decompose the $\mathrm{Cu}$ precursors and form $\mathrm{CuO}$, while the sputtering process can be done at room temperature in vacuum. As a consequence, the main structural characteristics of the supporting powder remained unaltered.

The morphology of all the $\mathrm{Cu} / \mathrm{TiO}_{2}$ catalysts was determined by transmission electron microscopy. Typical TEM images of the $\mathrm{Cu} / \mathrm{TiO}_{2}$ catalysts are presented in Figure 4. The catalysts made via the sputtering process exhibited an irregular shape with well-dispersed $\mathrm{Cu}$ particles of a size around 2 to $6 \mathrm{~nm}$. The irregular metal particles were the specific structure of the deposited metal prepared by using the pulsed magnetron sputtering process [29-31] whereas the impregnation- made catalysts exhibited spherical $\mathrm{Cu}$ clusters deposited on the $\mathrm{TiO}_{2}$ supports.

Photoluminescence spectroscopy is used to investigate the efficiency of charge carrier trapping, immigration and transfer in a photocatalysts. Figure 5 shows the PL spectra of all $\mathrm{Cu} / \mathrm{TiO}_{2}$ catalysts. There are many PL peaks can be detected in the visible region. The peak at $436 \mathrm{~nm}$ corresponded to the self-trapped electron localized on $\mathrm{TiO}_{6}[32]$ and the peaks at 469, $484,492 \mathrm{~nm}$ corresponded to the oxygen vacancies with two trapped electrons on $\mathrm{TiO}_{2}$ surface[33, 34]. From our results, the PL spectra decreased as the $\mathrm{Cu}$ loading content increased for both preparation methods except for the impregnation- made $\mathrm{Cu}$ supported on rutile $\mathrm{TiO}_{2}$ support in which doping with $\mathrm{Cu}$ resulted in an increase of PL signal (except IM2- Rut). PL spectroscopy measures the energy release during the electron-hole recombination process, therefore decrease of photoluminescence energy suggests the reduction of recombination rate. Decreasing of the PL signal after doping with $\mathrm{Cu}$ was attributed to the trapping of photoelectron 
from the conduction band of $\mathrm{TiO}_{2}$ by $\mathrm{Cu}^{2+}$, which could slow down the electron- hole recombination process.

XPS was used to investigate the surface properties of each element in the obtained $\mathrm{Cu} / \mathrm{TiO}_{2}$ catalysts. The XPS spectra of $\mathrm{Ti} 2 \mathrm{p}, \mathrm{O} 1 \mathrm{~s}$ and $\mathrm{Cu} 2 \mathrm{p}$ of all $\mathrm{Cu} / \mathrm{TiO}_{2}$ catalysts are shown in Figure 6. Generally, the binding energies corresponding to Ti $2 \mathrm{p}_{1 / 2}$ and $\mathrm{Ti} 2 \mathrm{p}_{3 / 2}$ in pure $\mathrm{TiO}_{2}$ were located at around 465 and $459 \mathrm{eV}$, respectively. These peaks corresponded to the $\mathrm{Ti}^{4+}$ valence state on lattice oxygen[35-37]. The two shoulder peaks centered at 463 and $457.3 \mathrm{eV}$ could be assigned to $\mathrm{Ti}_{2} \mathrm{O}_{3}$ corresponding with $\mathrm{Ti}^{3+}$ valence state[ $[38,39]$. The characteristic peaks of Ti $2 \mathrm{p}$ did not change after addition of copper by both preparation methods. Figure $6 \mathrm{~b}$ shows the XPS spectra of the $\mathrm{O} 1 \mathrm{~s}$ for the $\mathrm{Cu} / \mathrm{TiO}_{2}$ catalysts. Both catalysts showed main peaks and a shoulder centered at 530.7 and $532 \mathrm{eV}$, which were assigned to lattice oxide ions in $\mathrm{TiO}_{2}$ and the hydroxyl groups on the $\mathrm{TiO}_{2}$ surface, respectively[40]. The characteristic peaks of $\mathrm{Cu} 2 \mathrm{p}_{3 / 2}$ and $\mathrm{Cu} 2 \mathrm{p}_{1 / 2}$ peaks of the prepared catalysts by both methods were located around 933.6-934.2 eV and 953.1-954.9 eV, respectively. The satellite peak also presented at $944 \mathrm{eV}$. These peaks were consistent with those of the $\mathrm{Cu}^{2+}$ cations[41]. A small shift to higher binding energies ( $1 \mathrm{eV}$ ) was observed from impregnation- made catalyst, suggesting the different interaction between $\mathrm{Cu}$ and $\mathrm{TiO}_{2}$ support.

\subsection{Photocatalytic activity}

The photocatalytic activity of all the $\mathrm{Cu} / \mathrm{TiO}_{2}$ catalysts were evaluated by the photocatalytic reduction of $\mathrm{CO}_{2}$ in water at ambient temperature under $\mathrm{UV}$-light irradiation. 
The control experiment showed that there were no hydrocarbon products in the absence of photocatalysts or UV light irradiation. This suggests that the hydrocarbon product can be produced only by photocatalytic reaction using photocatalysts. From our test results, methane was the main product obtained from all the $\mathrm{Cu} / \mathrm{TiO}_{2}$ catalysts. Figure 7 shows the graph of the $\mathrm{CH}_{4}$ production yield of all the samples. Among the three $\mathrm{TiO}_{2}$ supports, rutile $\mathrm{TiO}_{2}$ exhibited the highest $\mathrm{CH}_{4}$ production yield. Deposition of $\mathrm{Cu}$ by magnetron sputtering on the $\mathrm{TiO}_{2}$ support increased the $\mathrm{CH}_{4}$ production yield. Loading small amounts of $\mathrm{Cu}$ by the impregnation method also improved the $\mathrm{CH}_{4}$ production yield, however, further increase of $\mathrm{Cu}$ doping content, the $\mathrm{CH}_{4}$ production yield for all the $\mathrm{TiO}_{2}$ supports decreased. Quantum efficiency of the photocatalytic $\mathrm{CO}_{2}$ reduction of all catalysts have also been calculated and reported in Table 2. The $\%$ quantum efficiency was calculated to be in the range of 0.08 to $0.74 \%$.

Improvement of the photocatalytic efficiency of $\mathrm{TiO}_{2}$ after $\mathrm{Cu}$ deposition can be explained by the reduction of the probability of photoexcited $\mathrm{e}^{-}$and hole $\mathrm{h}^{+}$recombination due to the electron trapping of $\mathrm{Cu}$ clusters. However, in the case of impregnation-made catalysts, increasing the $\mathrm{Cu}$ loading content also reduced band gap energy, which made energy level between the conduction and valence bands became narrower and promoted the electron hole recombination. Whilst, in the case of sputtered catalysts, the band gap energy did not change much, therefore, it was beneficial for the trapping process without the penalty from narrowing the band gap. Moreover, increasing of $\mathrm{Cu}$ loading on $\mathrm{TiO}_{2}$ surface also resulted in the coverage of $\mathrm{Cu}$ species on $\mathrm{TiO}_{2}$ surface, which could block the light on $\mathrm{TiO}_{2}$ surface.

In order to investigate the stability and the recyclability of the prepared catalysts, the photocatalytic $\mathrm{CO}_{2}$ reduction performances of the $\mathrm{Cu}$ deposited on $\mathrm{P} 25-\mathrm{TiO}_{2}$ catalysts prepared by both methods were determined repeatedly for three consecutive batches. The used catalysts 
were recovered by using centrifugal and filtration from the obtained reaction mixture and then were re-used. Figure 8 shows the plot of $\mathrm{CH}_{4}$ production yield obtained from various cycles. The $\mathrm{CH}_{4}$ production yield was found to be quite stable with negligible loss (less than $15 \%$ ). Such results suggest that the prepared $\mathrm{Cu} / \mathrm{TiO}_{2}$ catalyst can be reused for a long-term application.

\section{Conclusions}

Reactive magnetron sputtering was used to deposit $\mathrm{Cu}$ clusters on various $\mathrm{TiO}_{2}$ supports. The $\mathrm{Cu}$ loading content increased linearly with increasing sputtering time due to the constant $\mathrm{Cu}$ flux in the sputtering process. Irregular shaped $\mathrm{Cu}$ clusters were observed on the catalysts produced by sputtering, whereas spherical clusters were mainly obtained by impregnation. The UV-Vis spectra results revealed that increasing the $\mathrm{Cu}$ deposition content by magnetron sputtering slightly decreased the band gap energy whereas impregnation method led to a significant change in the band gap energy due to the different interactions between the $\mathrm{Cu}$ species and the $\mathrm{TiO}_{2}$ supports. The sputtered $\mathrm{Cu} / \mathrm{TiO}_{2}$ catalysts exhibited higher photocatalytic activity than the undoped $\mathrm{TiO}_{2}$ supports and the impregnation-made ones. The electron trapping of copper species, which prolonged the electron-hole recombination process, promoted photocatalytic activity of the $\mathrm{Cu}$-doped catalysts with a little change in the band gap energy.

\section{Acknowledgments:}

This research is supported by Newton Mobility Grants and Malaysia-Thailand Joint Authority Research Cess Fund Project. 


\section{References}

[1] I.-H. Tseng, W.-C. Chang, J.C. Wu, Photoreduction of $\mathrm{CO}_{2}$ using sol-gel derived titania and titania-supported copper catalysts, Applied Catalysis B: Environmental, 37 (2002) 37-48.

[2] K. Kočí, L. Obalová, L. Matějová, D. Plachá, Z. Lacný, J. Jirkovský, O. Šolcová, Effect of $\mathrm{TiO}_{2}$ particle size on the photocatalytic reduction of $\mathrm{CO}_{2}$, Applied Catalysis B: Environmental, 89 (2009) 494-502.

[3] Q. Li, L. Zong, C. Li, J. Yang, Reprint of "Photocatalytic reduction of $\mathrm{CO}_{2}$ on $\mathrm{MgO} / \mathrm{TiO}_{2}$ nanotube films", Applied Surface Science, 319 (2014) 16-20.

[4] W. Qingli, Z. Zhaoguo, C. Xudong, H. Zhengfeng, D. Peimei, C. Yi, Z. Xiwen, Photoreduction of $\mathrm{CO}_{2}$ using black $\mathrm{TiO}_{2}$ films under solar light, Journal of $\mathrm{CO}_{2}$ Utilization, 12 (2015) 7-11.

[5] W.A. Thompson, C. Perier, M.M. Maroto-Valer, Systematic study of sol-gel parameters on $\mathrm{TiO}_{2}$ coating for $\mathrm{CO}_{2}$ photoreduction, Applied Catalysis B: Environmental, 238 (2018) 136-146.

[6] Z. Xiong, H. Wang, N. Xu, H. Li, B. Fang, Y. Zhao, J. Zhang, C. Zheng, Photocatalytic reduction of $\mathrm{CO}_{2}$ on $\mathrm{Pt}^{2+}-\mathrm{Pt}^{0} / \mathrm{TiO}_{2}$ nanoparticles under $\mathrm{UV} / \mathrm{V}$ is light irradiation: a combination of $\mathrm{Pt}^{2+}$ doping and $\mathrm{Pt}$ nanoparticles deposition, International journal of hydrogen energy, 40 (2015) 10049-10062.

[7] Z. Xiong, Z. Lei, C.-C. Kuang, X. Chen, B. Gong, Y. Zhao, J. Zhang, C. Zheng, J.C. Wu, Selective photocatalytic reduction of $\mathrm{CO}_{2}$ into $\mathrm{CH}_{4}$ over Pt- $\mathrm{Cu}_{2} \mathrm{O} \mathrm{TiO}_{2}$ nanocrystals: the interaction between $\mathrm{Pt}$ and $\mathrm{Cu}_{2} \mathrm{O}$ cocatalysts, Applied Catalysis B: Environmental, 202 (2017) 695-703. 
[8] M. Anpo, H. Yamashita, Y. Ichihashi, Y. Fujii, M. Honda, Photocatalytic reduction of $\mathrm{CO}_{2}$ with $\mathrm{H}_{2} \mathrm{O}$ on titanium oxides anchored within micropores of zeolites: effects of the structure of the active sites and the addition of Pt, The Journal of Physical Chemistry B, 101 (1997) 26322636.

[9] S. Sato, T. Morikawa, S. Saeki, T. Kajino, T. Motohiro, VisibleDlightDinduced selective $\mathrm{CO}_{2}$ reduction utilizing a ruthenium complex electrocatalyst linked to ap $\square$ type nitrogen $\square$ doped $\mathrm{Ta}_{2} \mathrm{O}_{5}$ semiconductor, Angewandte Chemie, 122 (2010) 5227-5231.

[10] T. Inoue, A. Fujishima, S. Konishi, K. Honda, Photoelectrocatalytic reduction of carbon dioxide in aqueous suspensions of semiconductor powders, Nature, 277 (1979) 637-638.

[11] D. Liu, Y. Fernández, O. Ola, S. Mackintosh, M. Maroto-Valer, C.M. Parlett, A.F. Lee, J.C. $\mathrm{Wu}, \mathrm{On}$ the impact of $\mathrm{Cu}$ dispersion on $\mathrm{CO}_{2}$ photoreduction over $\mathrm{Cu} / \mathrm{TiO}_{2}$, Catalysis Communications, 25 (2012) 78-82.

[12] S. Das, W.W. Daud, A review on advances in photocatalysts towards $\mathrm{CO}_{2}$ conversion, Rsc Advances, 4 (2014) 20856-20893.

[13] S. Krejčíková, L. Matějová, K. Kočí, L. Obalová, Z. Matěj, L. Čapek, O. Šolcová, Preparation and characterization of $\mathrm{Ag}$ - doped crystalline titania for photocatalysis applications, Applied Catalysis B: Environmental, 111 (2012) 119-125.

[14] O. Ola, M.M. Maroto-Valer, Review of material design and reactor engineering on TiO2 photocatalysis for $\mathrm{CO}_{2}$ reduction, Journal of Photochemistry and Photobiology $\mathrm{C}$ : Photochemistry Reviews, 24 (2015) 16-42.

[15] J. Low, B. Cheng, J. Yu, Surface modification and enhanced photocatalytic $\mathrm{CO}_{2}$ reduction performance of $\mathrm{TiO}_{2}$ : a review, Applied Surface Science, 392 (2017) 658-686. 
[16] Y. Li, X. Deng, J. Tian, Z. Liang, H. Cui, $\mathrm{Ti}_{3} \mathrm{C}_{2}$ MXene-derived $\mathrm{Ti}_{3} \mathrm{C}_{2} / \mathrm{TiO}_{2}$ nanoflowers for noble-metal-free photocatalytic overall water splitting, Applied Materials Today, 13 (2018) 217-227.

[17] B. Sun, Y. Qian, Z. Liang, Y. Guo, Y. Xue, J. Tian, H. Cui, Oxygen vacancy-rich $\mathrm{BiO}_{2-x}$ ultra-thin nanosheet for efficient full-spectrum responsive photocatalytic oxygen evolution from water splitting, Solar Energy Materials and Solar Cells, 195 (2019) 309-317.

[ 18 l $]$ B. Yin, C. Liu, Convenient Synthesis and Enhanced Photocatalytic Activity of $\mathrm{BiOI} / \mathrm{BiOBr}$ Nanostructures with Different Morphologies, Journal of nanoscience and nanotechnology, 18 (2018) 4771-4779.

[19] Y. Li, T. Li, J. Tian, X. Wang, H. Cui, $\mathrm{TiO}_{2}$ Nanobelts Decorated with $\operatorname{In}_{2} \mathrm{~S}_{3}$ Nanoparticles as Photocatalysts with Enhanced FulluSolarDSpectrum (UV-vis-NIR) Photocatalytic Activity toward the Degradation of Tetracycline, Particle \& Particle Systems Characterization, 34 (2017) 1700127.

[20] H.W. Nasution, E. Purnama, S. Kosela, J. Gunlazuardi, Photocatalytic reduction of $\mathrm{CO}_{2}$ on copper- doped Titania catalysts prepared by improved-impregnation method, Catalysis Communications, 6 (2005) 313-319.

[2 1] W. - N. Wang, W. - J. An, B. Ramalingam, S. Mukherjee, D. M. Niedzwiedzki, S. Gangopadhyay, P. Biswas, Size and structure matter: enhanced $\mathrm{CO}_{2}$ photoreduction efficiency by size-resolved ultrafine Pt nanoparticles on $\mathrm{TiO}_{2}$ single crystals, Journal of the American chemical society, 134 (2012) 11276-11281. 
[22] S.t. Neaţu, J.A. Maciá-Agulló, P. Concepción, H. Garcia, Gold-copper nanoalloys supported on $\mathrm{TiO}_{2}$ as photocatalysts for $\mathrm{CO}_{2}$ reduction by water, Journal of the American Chemical Society, 136 (2014) 15969-15976.

[23] K. Kočí, K. Matějů, L. Obalová, S. Krejčíková, Z. Lacný, D. Plachá, L. Čapek, A. Hospodková, O. Šolcová, Effect of silver doping on the $\mathrm{TiO}_{2}$ for photocatalytic reduction of CO2, Applied Catalysis B: Environmental, 96 (2010) 239-244.

[24] L. Shindume, Z. Zhao, N. Wang, H. Liu, A. Umar, J. Zhang, T. Wu, Z. Guo, Enhanced photocatalytic activity of $\mathrm{B}, \mathrm{N}$-codoped $\mathrm{TiO}_{2}$ by a new molten nitrate process, Journal of Nanoscience and Nanotechnology, 19 (2019) 839-849.

[25] H. Yan, T. Zhao, X. Li, C. Hun, Synthesis of Cu-doped nano- $\mathrm{TiO}_{2}$ by detonation method, Ceramics International, 41 (2015) 14204-14211.

[26] Y. Li, W.-N. Wang, Z. Zhan, M.-H. Woo, C.-Y. Wu, P. Biswas, Photocatalytic reduction of $\mathrm{CO}_{2}$ with $\mathrm{H}_{2} \mathrm{O}$ on mesoporous silica supported $\mathrm{Cu} / \mathrm{TiO}_{2}$ catalysts, Applied Catalysis $\mathrm{B}$ : Environmental, 100 (2010) 386-392.

[27] M. Ratova, R. Klaysri, P. Praserthdam, P.J. Kelly, Visible light active photocatalytic Cdoped titanium dioxide films deposited via reactive pulsed DC magnetron co-sputtering: Properties and photocatalytic activity, Vacuum, 149 (2018) 214-224.

[28] Y. Zhang, H. Ma, M. Yi, Z. Shen, X. Yu, X. Zhang, Magnetron-sputtering fabrication of noble metal nanodots coated $\mathrm{TiO}_{2}$ nanoparticles with enhanced photocatalytic performance, Materials \& Design, 125 (2017) 94-99. 
[29] H. Wang, Y. Li, X. Ba, L. Huang, Y. Yu, TiO 2 thin films with rutile phase prepared by DC magnetron co-sputtering at room temperature: effect of $\mathrm{Cu}$ incorporation, Applied Surface Science, 345 (2015) 49-56.

[30] L. Chen, M.E. Graham, G. Li, D.R. Gentner, N.M. Dimitrijevic, K.A. Gray, Photoreduction of $\mathrm{CO}_{2}$ by $\mathrm{TiO}_{2}$ nanocomposites synthesized through reactive direct current magnetron sputter deposition, Thin Solid Films, 517 (2009) 5641-5645.

[3 1] W. Hui, S. Guodong, Z. Xiaoshu, Z. Wei, H. Lin, Y. Ying, In-situ synthesis of $\mathrm{TiO}_{2}$ rutile/ anatase heterostructure by DC magnetron sputtering at room temperature and thickness effect of outermost rutile layer on photocatalysis, Journal of Environmental Sciences, 60 (2017) $33-42$.

[32] H. Khan, D. Berk, Effect of a chelating agent on the physicochemical properties of $\mathrm{TiO}_{2}$ : characterization and photocatalytic activity, Catalysis letters, 144 (2014) 890-904.

[3 3] P. Verma, S. K. Samanta, Degradation kinetics of pollutants present in a simulated wastewater matrix using $\mathrm{UV} / \mathrm{TiO}_{2}$ photocatalysis and its microbiological toxicity assessment, Research on Chemical Intermediates, 43 (2017) 6317-6341.

[34] Y. Jiang, Z. Yang, P. Zhang, H. Jin, Y. Ding, Natural assembly of a ternary Ag-SnS$\mathrm{TiO}_{2}$ photocatalyst and its photocatalytic performance under simulated sunlight, RSC Advances, 8 (2018) 13408-13416.

[ 3 5] K. Imamura, S. - i. Iwasaki, T. Maeda, K. Hashimoto, B. Ohtani, H. Kominami, Photocatalytic reduction of nitrobenzenes to aminobenzenes in aqueous suspensions of titanium (IV) oxide in the presence of hole scavengers under deaerated and aerated conditions, Physical Chemistry Chemical Physics, 13 (2011) 5114-5119. 
[36] R. Bhosale, R. Hyam, P. Dhanya, S. Ogale, Chlorate ion mediated rutile to anatase reverse phase transformation in the $\mathrm{TiO}_{2}$ nanosystem, Dalton Transactions, 40 (2011) 11374-11377. [37] K. Imamura, K. Hashimoto, H. Kominami, Chemoselective reduction of nitrobenzenes to aminobenzenes having reducible groups by a titanium (IV) oxide photocatalyst under gas-and metal-free conditions, Chemical Communications, 48 (2012) 4356-4358.

[38] N.R.F. Machado, V.S. Santana, Influence of thermal treatment on the structure and photocatalytic activity of $\mathrm{TiO}_{2} \mathrm{P} 25$, Catalysis Today, 107 (2005) 595-601.

[39] G. Wang, L. Xu, J. Zhang, T. Yin, D. Han, Enhanced photocatalytic activity of powders (P25) via calcination treatment, International Journal of Photoenergy, 2012 (2012).

[40] A. Naldoni, M. Allieta, S. Santangelo, M. Marelli, F. Fabbri, S. Cappelli, C.L. Bianchi, R. Psaro, V. Dal Santo, Effect of nature and location of defects on bandgap narrowing in black $\mathrm{TiO}_{2}$ nanoparticles, Journal of the American Chemical Society, 134 (2012) 7600-7603.

[ 4 1 ] M. - K. Jeon, J. - W. Park, M. Kang, Hydrogen production from methanol/ water decomposition in a liquid photosystem using the anatase and rutile forms of $\mathrm{Cu}-\mathrm{TiO}_{2}$, Journal of Industrial and Engineering Chemistry, 13 (2007) 84-91. 
Table 1 Summary of the characteristic properties of $\mathrm{Cu} / \mathrm{TiO}_{2}$ catalysts

\begin{tabular}{|c|c|c|c|c|c|}
\hline \multirow{2}{*}{ Catalyst } & \multicolumn{2}{|c|}{${ }^{\mathrm{a}}$ Crystallite size (nm) } & \multirow{2}{*}{$\begin{array}{c}{ }^{\mathrm{b}} \text { Surface area } \\
\left(\mathrm{m}^{2} / \mathrm{g}\right)\end{array}$} & \multirow{2}{*}{$\begin{array}{c}\text { 'band gap energy } \\
(\mathrm{eV})\end{array}$} & \multirow{2}{*}{$\begin{array}{c}{ }^{\mathrm{d}} \mathrm{Wt} \% \text { of } \\
\mathrm{Cu}\end{array}$} \\
\hline & Anatase & Rutile & & & \\
\hline $\mathrm{P} 25-\mathrm{TiO}_{2}$ & 20 & 23 & 54 & 3.21 & - \\
\hline SP1-P25 & 19 & 25 & 53 & 3.09 & 0.73 \\
\hline SP2-P25 & 18 & 24 & 54 & 3.04 & 1.44 \\
\hline SP3-P25 & 19 & 23 & 54 & 3.01 & 2.21 \\
\hline IM1-P25 & 18 & 22 & 51 & 2.96 & 0.68 \\
\hline IM2-P25 & 18 & 22 & 52 & 2.55 & 1.57 \\
\hline IM3-P25 & 17 & 21 & 52 & 2.53 & 2.47 \\
\hline Ana- $\mathrm{TiO}_{2}$ & 20 & - & 111 & 3.23 & - \\
\hline SP1-Ana & 18 & - & 110 & 3.21 & 0.33 \\
\hline SP2-Ana & 20 & - & 110 & 3.2 & 0.65 \\
\hline SP3-Ana & 19 & - & 106 & 3.16 & 1.18 \\
\hline IM1-Ana & 17 & - & 80 & 3.14 & 0.34 \\
\hline IM2-Ana & 19 & - & 81 & 3.01 & 0.70 \\
\hline IM3-Ana & 18 & - & 79 & 2.83 & 1.40 \\
\hline Rut- $\mathrm{TiO}_{2}$ & - & 23 & 171 & 3.17 & - \\
\hline SP1-Rut & - & 21 & 169 & 3.14 & 0.52 \\
\hline SP2-Rut & - & 17 & 170 & 3.09 & 1.18 \\
\hline SP3-Rut & - & 15 & 169 & 3.06 & 1.91 \\
\hline IM1-Rut & - & 19 & 144 & 2.83 & 0.57 \\
\hline IM2-Rut & - & 20 & 143 & 2.75 & 1.23 \\
\hline IM3-Rut & - & 18 & 142 & 2.68 & 2.11 \\
\hline
\end{tabular}

a Average crystalline size was determined by XRD using Scherrer equation.

$\mathrm{b}$ The BET surface area was determined by single point BET method.

${ }^{\mathrm{c}}$ band gap energy was calculated by UV-visible absorption spectra.

${ }^{\mathrm{d}}$ Weight percent was determined by ICP. 
Table $2 \mathrm{CH}_{4}$ production yield after $6 \mathrm{~h}$ of irradiation and formal \% quantum efficiency (Q.E.) of all catalysts

\begin{tabular}{|c|c|c|}
\hline Catalyst & $\mathrm{CH}_{4}$ yields $\left(\mu\right.$ mole.gcat. $\left.\mathrm{h}^{-1}\right)$ & Q.E. $(\%)$ \\
\hline $\mathrm{P} 25-\mathrm{TiO}_{2}$ & 0.27 & 0.08 \\
\hline SP1-P25 & 1.25 & 0.39 \\
\hline SP2-P25 & 1.15 & 0.36 \\
\hline SP3-P25 & 1.86 & 0.59 \\
\hline IM1-P25 & 0.74 & 0.23 \\
\hline IM2-P25 & 1.45 & 0.46 \\
\hline IM3-P25 & 0.88 & 0.28 \\
\hline Ana- $\mathrm{TiO}_{2}$ & 0.59 & 0.19 \\
\hline SP1-Ana & 0.87 & 0.27 \\
\hline SP2-Ana & 0.93 & 0.29 \\
\hline SP3-Ana & 1.23 & 0.39 \\
\hline IM1-Ana & 0.51 & 0.16 \\
\hline IM2-Ana & 1.1 & 0.35 \\
\hline IM3-Ana & 0.77 & 0.24 \\
\hline Rut- $\mathrm{TiO}_{2}$ & 1.39 & 0.44 \\
\hline SP1-Rut & 1.76 & 0.55 \\
\hline SP2-Rut & 1.53 & 0.48 \\
\hline SP3-Rut & 1.89 & 0.59 \\
\hline IM1-Rut & 1.09 & 0.34 \\
\hline IM2-Rut & 2.35 & 0.74 \\
\hline IM3-Rut & 1.35 & 0.42 \\
\hline
\end{tabular}




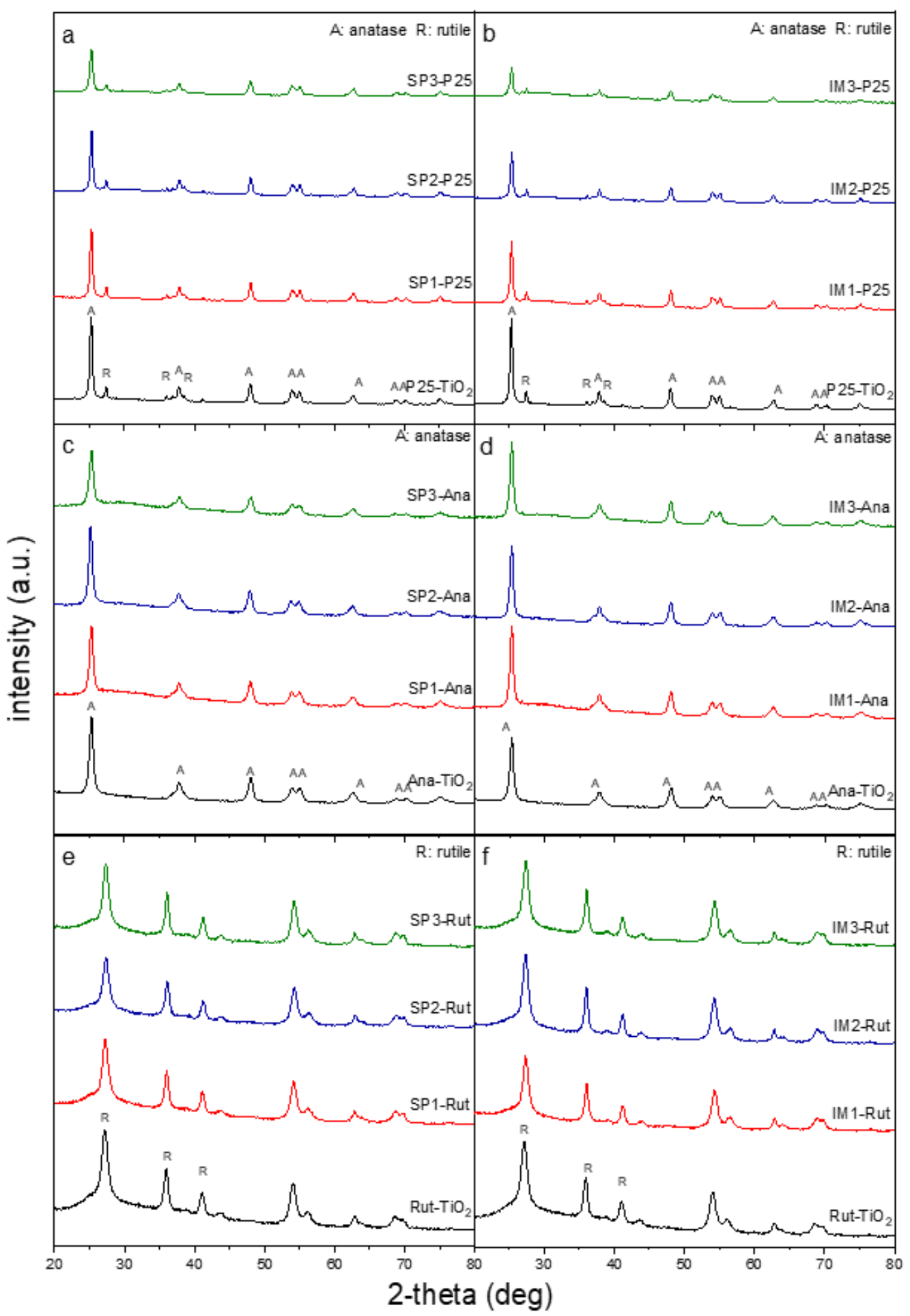

Figure 1 XRD patterns of P25, Ana and Rut modified with $\mathrm{Cu}$ nanoparticles prepared by magnetron sputtering $(\mathrm{a}, \mathrm{c}, \mathrm{e})$ and incipient wetness impregnation $(\mathrm{b}, \mathrm{d}, \mathrm{f})$ methods. 


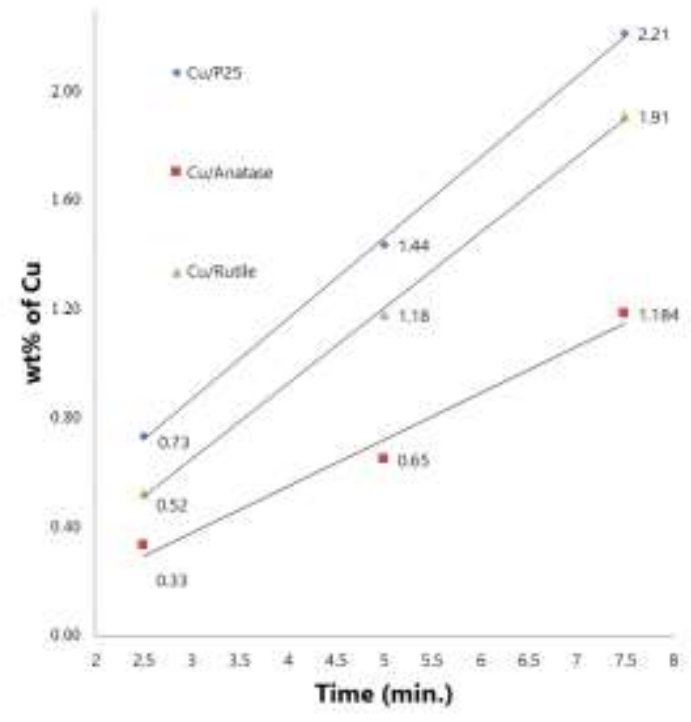

Figure 2. \%Wt. of $\mathrm{Cu}$-adhered onto $\mathrm{P} 25-\mathrm{TiO}_{2}, \mathrm{Ana}-\mathrm{TiO}_{2}$, and Rut- $\mathrm{TiO}_{2}$ supports prepared magnetron sputtering method. 


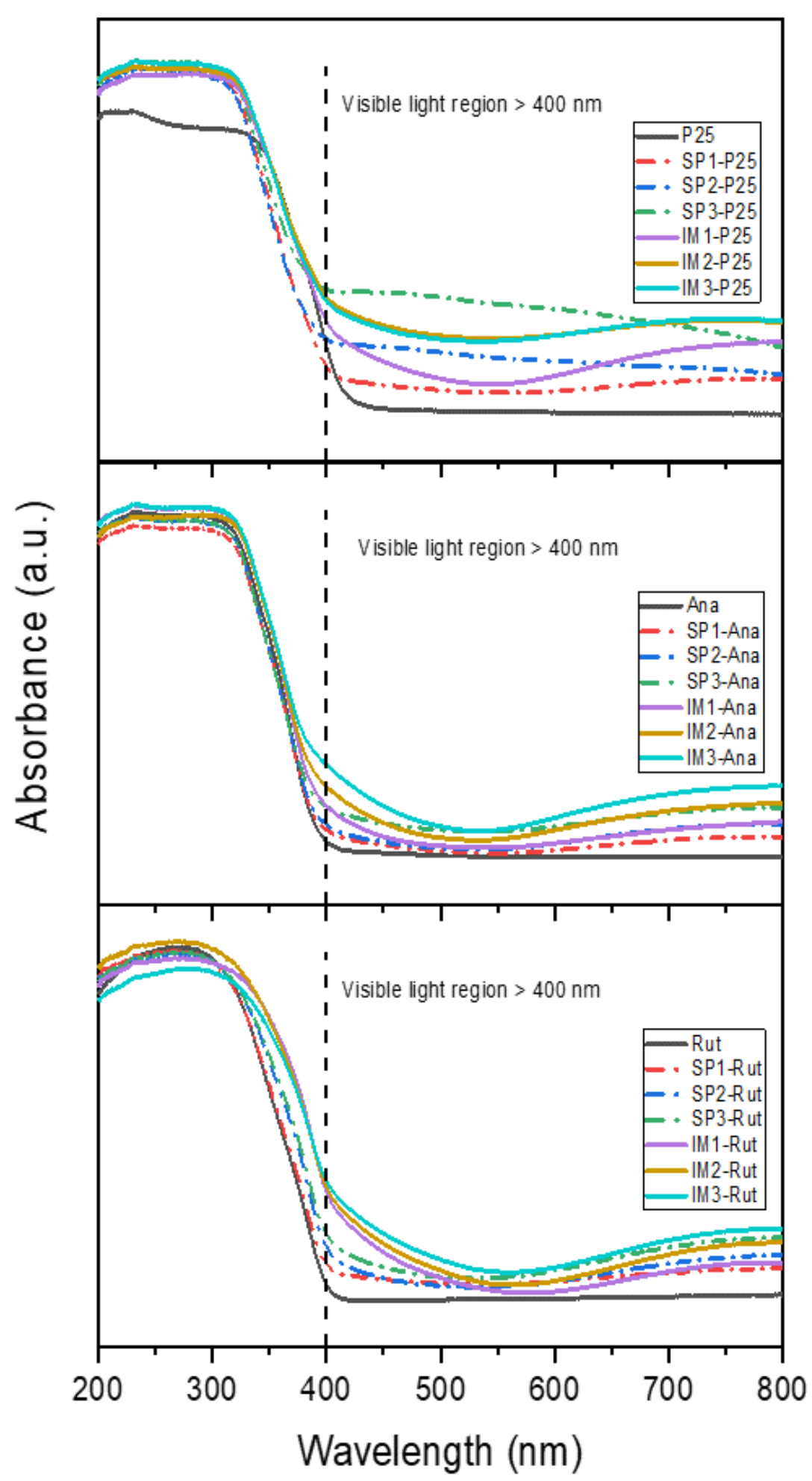

Figure 3. The UV-Vis absorption spectra of $\mathrm{P} 25-\mathrm{TiO}_{2}, \mathrm{Ana}-\mathrm{TiO}_{2}$ and Rut- $\mathrm{TiO}_{2}$ modified with $\mathrm{Cu}$ nanoparticles prepared by magnetron sputtering and incipient wetness impregnation methods. 

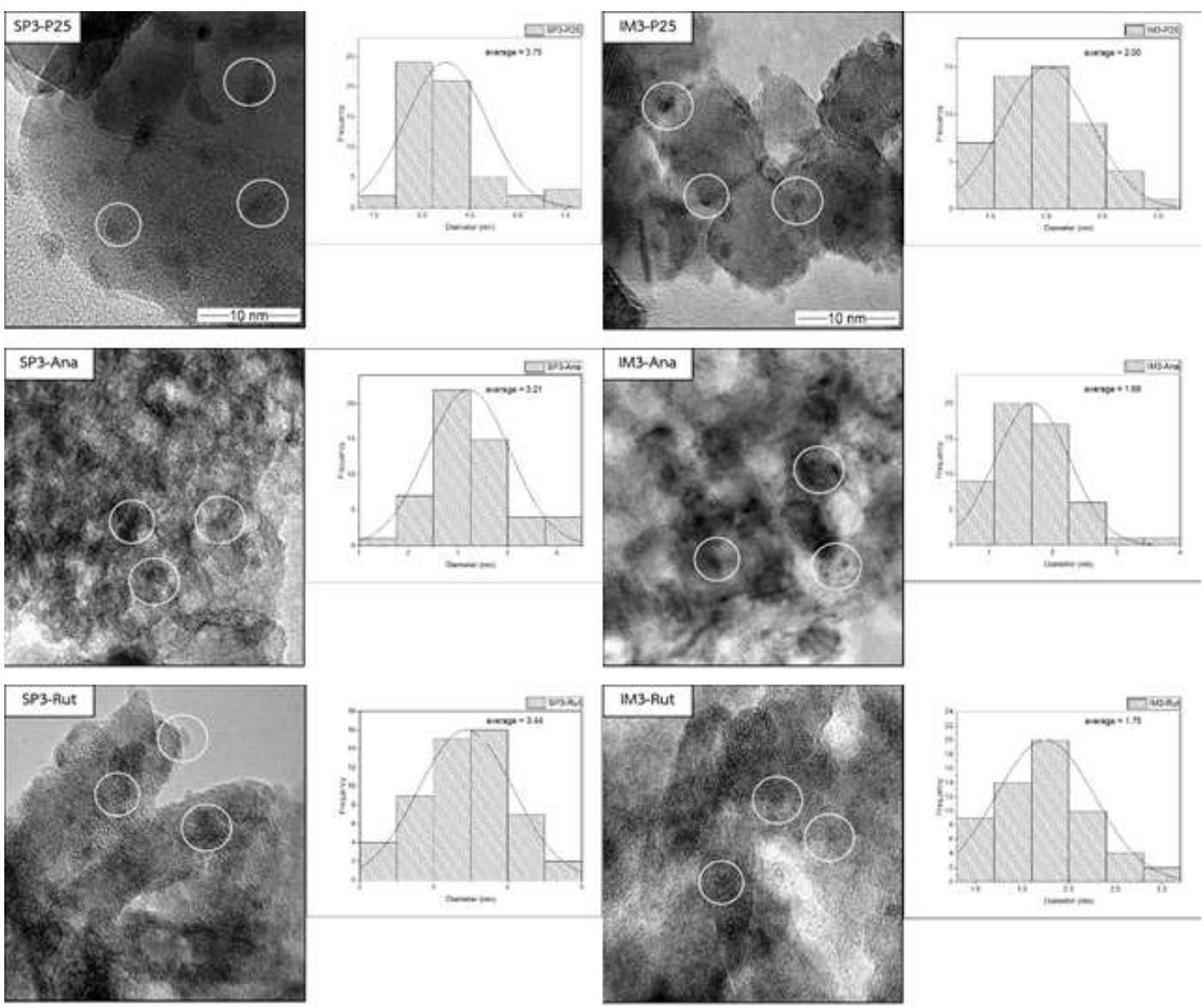

Figure 4.TEM images of $\mathrm{P} 25-\mathrm{TiO}_{2}, \mathrm{Ana}-\mathrm{TiO}_{2}$ and $\mathrm{Rut}-\mathrm{TiO}_{2}$ modified $\mathrm{Cu}$ nanoparticles prepared by magnetron sputtering method and incipient wetness impregnation. 

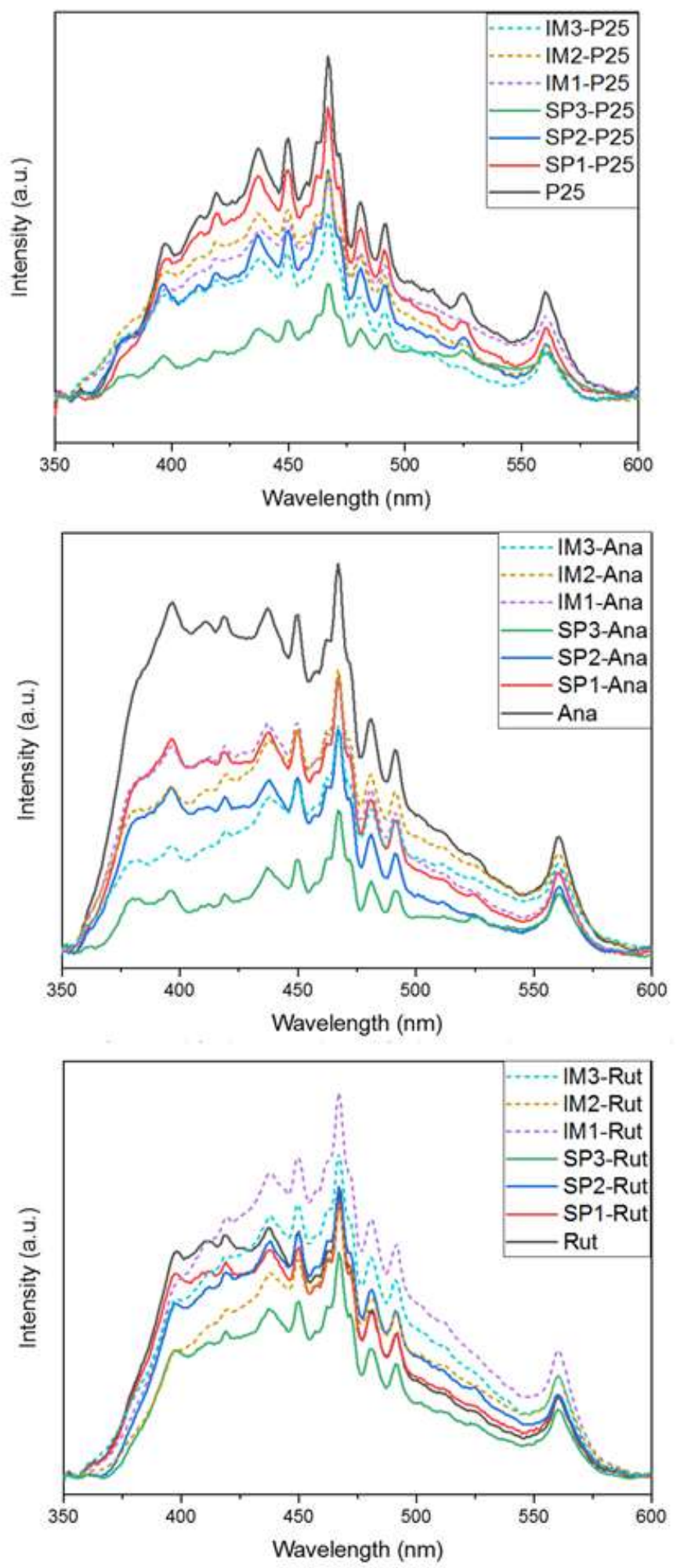

Figure 5. PL spectra of $\mathrm{P} 25-\mathrm{TiO} 2, \mathrm{Ana}-\mathrm{TiO}_{2}$ and $\mathrm{Rut}-\mathrm{TiO}_{2}$ modified $\mathrm{Cu}$ nanoparticles prepared by magnetron sputtering method and incipient wetness impregnation. 

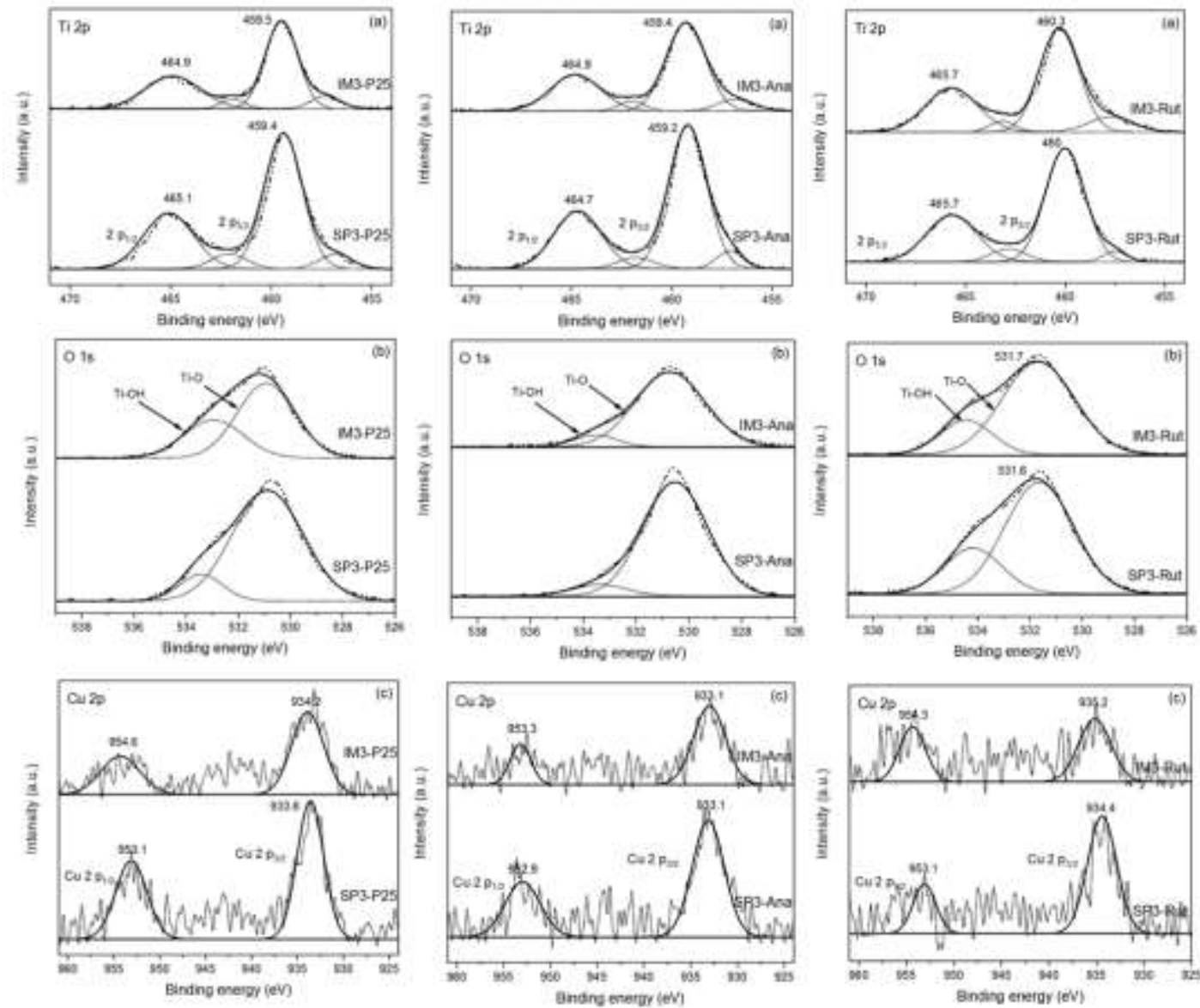

Figure 6. XPS spectra of $\mathrm{Ti} 2 \mathrm{p}, \mathrm{O}$ 1s and $\mathrm{Cu} 2 \mathrm{p}$ of $\mathrm{P} 25-\mathrm{TiO} 2, \mathrm{Ana}^{-\mathrm{TiO}_{2}}$ and $\mathrm{Rut}-\mathrm{TiO}_{2}$

modified $\mathrm{Cu}$ nanoparticles prepared by magnetron sputtering method and incipient wetness impregnation. 

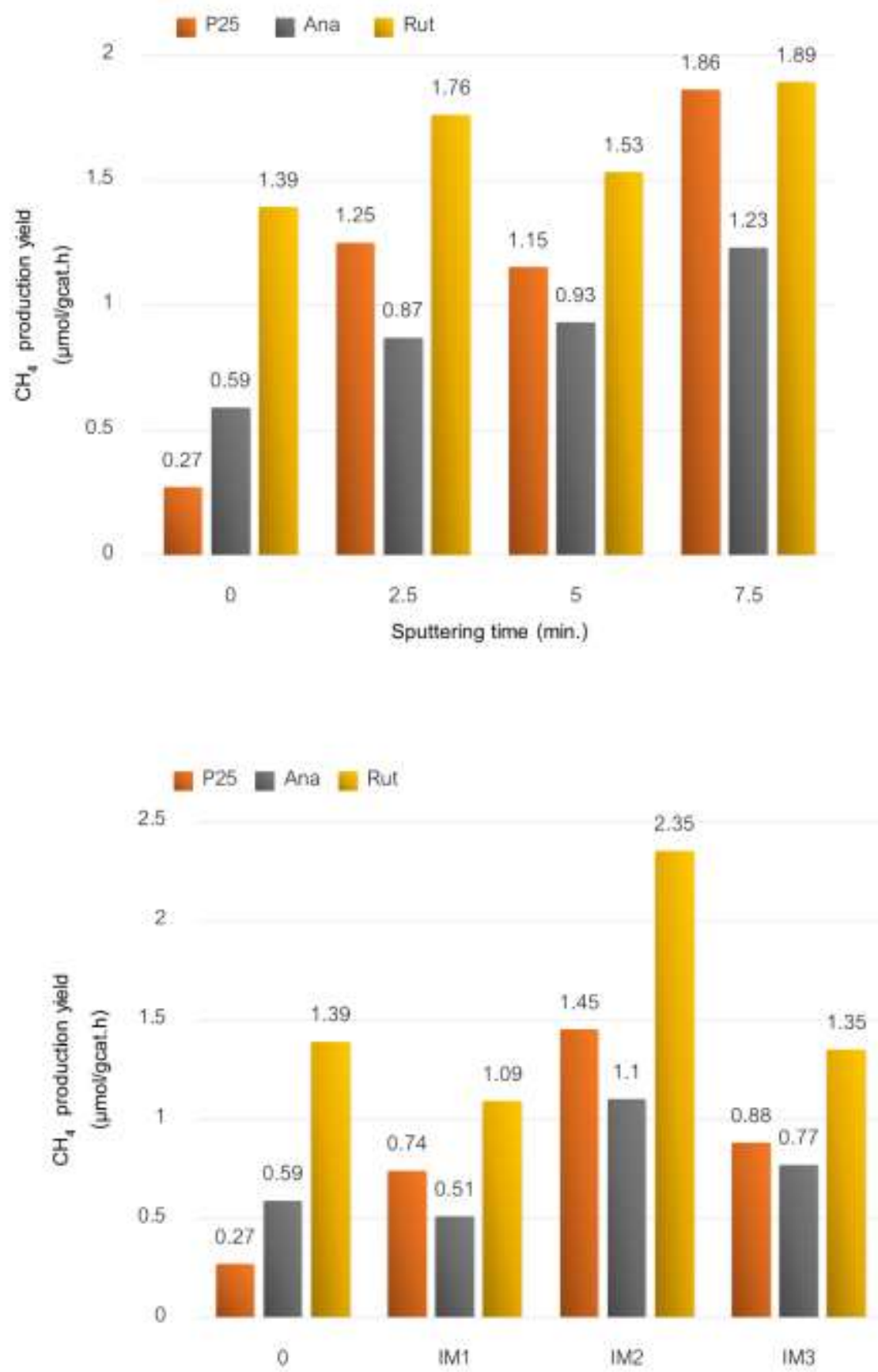

Figure 7. Comparison of $\mathrm{CH}_{4}$ production yield of $\mathrm{P} 25-\mathrm{TiO}_{2}, \mathrm{Ana}-\mathrm{TiO}_{2}$ and $\mathrm{Rut}-\mathrm{TiO}_{2}$ modified with $\mathrm{Cu}$ prepared by magnetron sputtering and incipient wetness impregnation methods. 

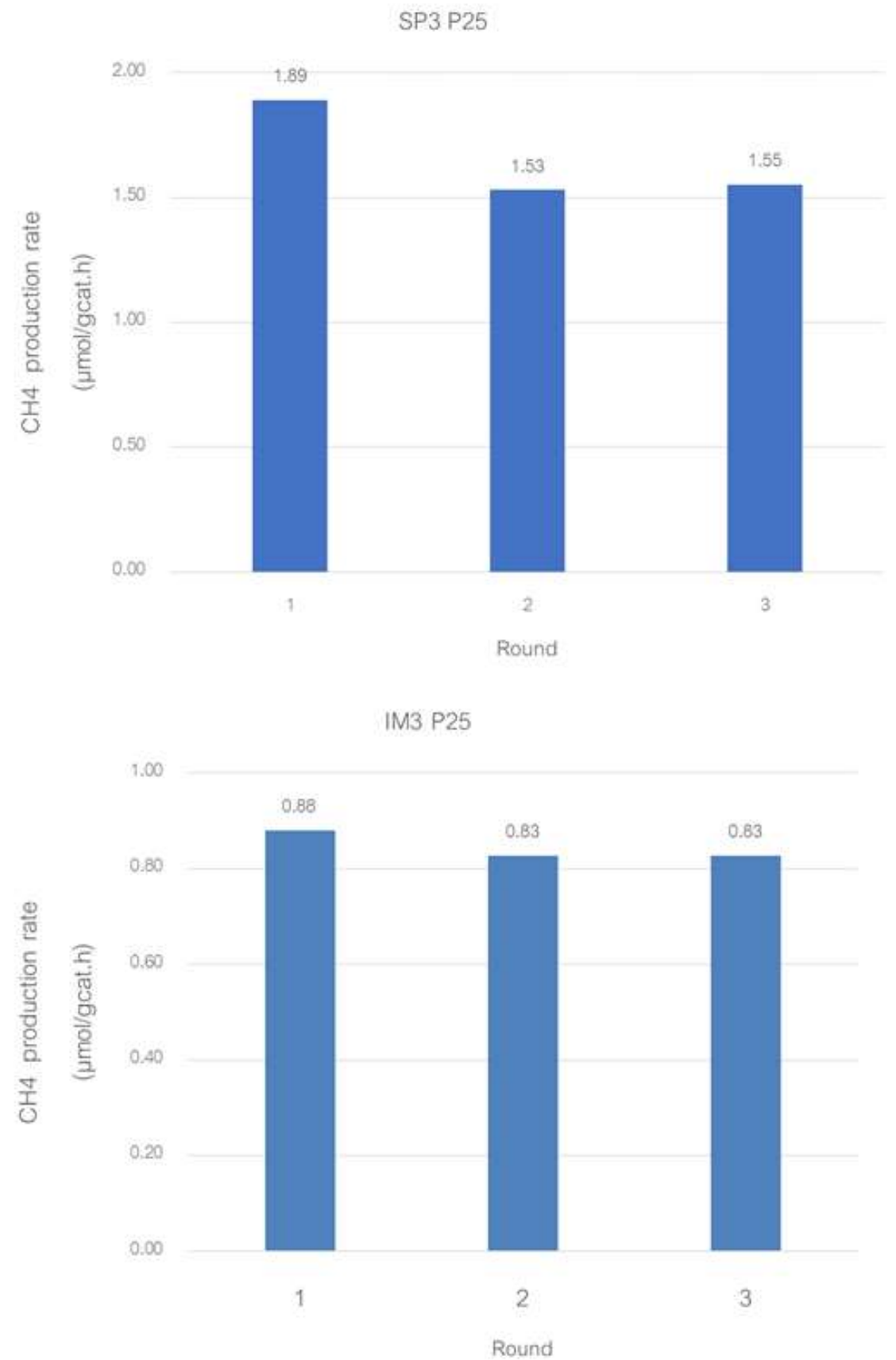

Figure 8 . The catalytic performance of $\mathrm{Cu}$ deposited on $\mathrm{P} 25$ prepared by magnetron sputtering and incipient wetness impregnation methods under UV light irradiated for $6 \mathrm{~h}$ at different cycles 